\title{
18
}

\section{Low Impact Development Modeling to Assess Localized Flood Reduction in Thailand}

\author{
T. Chaosakul, T. Koottatep and K. N. Irvine
}

The causes and impacts of, and emergency responses to, the recent catastrophic flooding in northern and central Thailand, including Bangkok, are reviewed. A number of short term and long term engineering solutions have been proposed to avoid or minimize future flooding impacts. Low impact development (LID) technologies might be one reasonable, sustainable, approach to solving urban drainage and water quality problems in Bangkok, but the local urban approaches should be integrated with watershed wide planning efforts.

PCSWMM was used to model single and multiple LID technologies in a case study of a peri-urban village near Bangkok as a preliminary exploration of LID benefits in terms of stormwater quantity and quality. A 2 y design storm for Thailand was used in the modeling. The design plans of LID technologies, using either CAD or Google SketchUp, were visualized through Google Earth, and were costed using local information.

All LID scenarios reduced combined sewer overflow (CSO) volume, CSO pollutant loadings and the durations of surface flooding, although single rain barrels installed at all houses had a relatively small (4\% to $9 \%$ reduction) impact. This may be related in part to the fact that a $2 \mathrm{y}$ storm in Thailand is more similar to a $50 \mathrm{y}$ or $100 \mathrm{y}$ storm in northeastern North America. The combined rain barrel and bioretention cell scenarios offered the greatest control in reducing CSO discharges, but the costs may be prohibitive in Thailand at present.

Chaosakul, T., T. Koottatep and K. Irvine. 2013. "Low Impact Development Modeling to Assess Localized Flood Reduction in Thailand." Journal of Water Management Modeling R246-18. doi: 10.14796/JWMM.R246-18.

(C) CHI 2013 www.chijournal.org ISSN: 2292-6062 (Formerly in Pragmatic Modeling of Urban Water Systems. ISBN: 978-0-9808853-8-5) 


\subsection{Introduction}

The city of Bangkok, Thailand, is located on the lower Chao Phraya river delta, which has a contributing basin of approximately $160000 \mathrm{~km}^{2}$, representing $30 \%$ of the entire area of the country (Molle, 2004; Figure 18.1). The southward flow of water towards Bangkok is managed through three larger dams, Bhumipol (storage capacity of $13.462 \mathrm{~km}^{3}$ ), Sirikit (storage capacity of $9.510 \mathrm{~km}^{3}$ ) and Pasak (storage capacity of $0.780 \mathrm{~km}^{3}$ ), together with a series of smaller dams, including Krasiew, Mae Ngat, Thap Salao, Mae Kuang, Kamphaeng Phet, Naresuan, Chao Phraya and Rama VI (Yoshito et al., 2003; Molle, 2004; Chaleeraktrakoon and Kangrang, 2007).

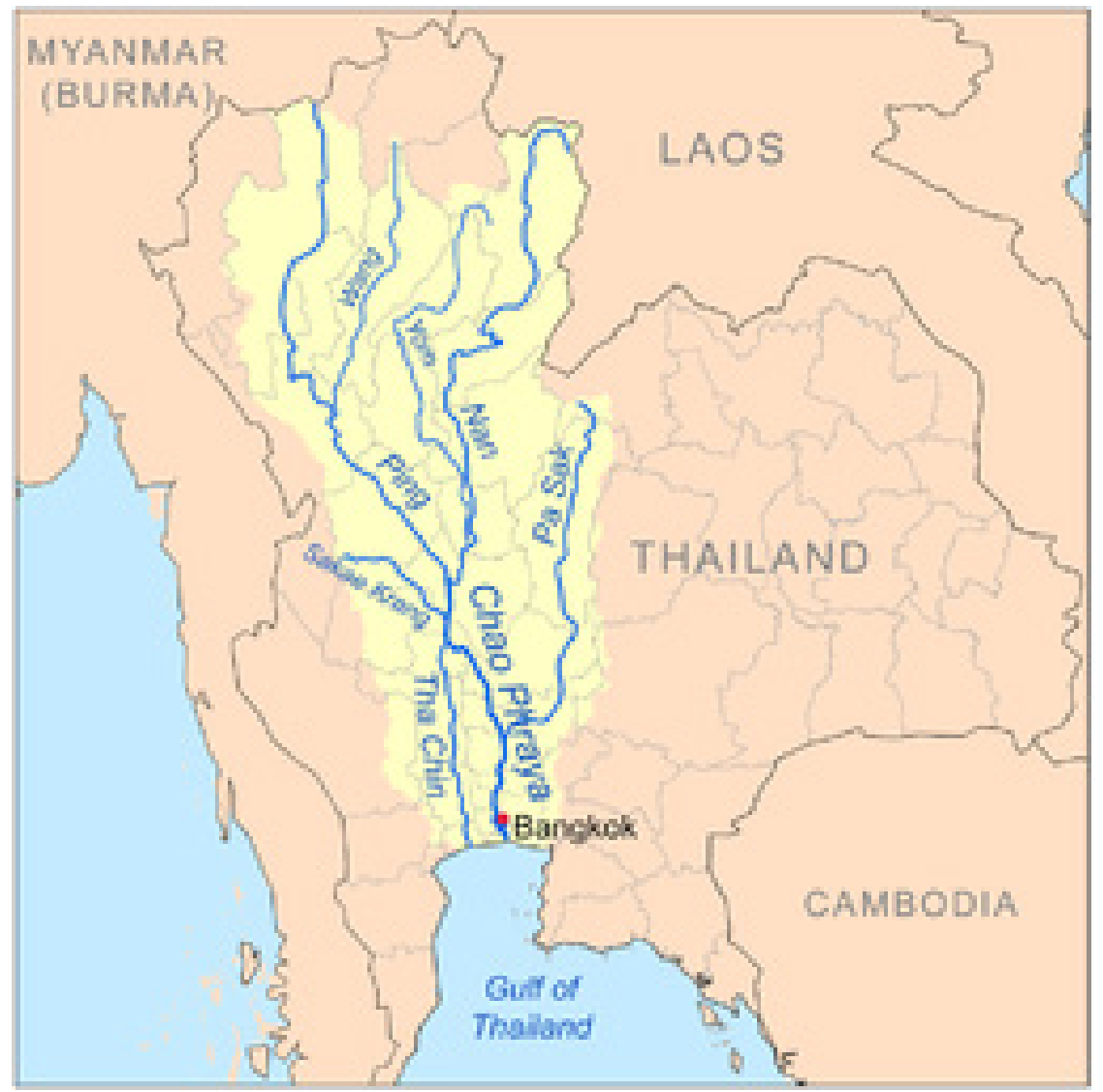

Figure 18.1 Chao Phraya watershed (http://en.wikipedia.org/wiki/Ping_ River). 
Although flooding occurs in various areas of Thailand as part of the annual monsoon cycle, the flood of 2011 was one of the largest on record, impacting some 2.3 million people and creating \$25 billion USD in damage (Royal Irrigation Department, Thailand, 2011; Thailand Research Fund, 2011; Science and Development Network, 2011).

The peak discharge flowing through Bangkok City in 2011 was $4700 \mathrm{~m}^{3} / \mathrm{s}$, nearly double the maximum channel capacity of $2500 \mathrm{~m}^{3} / \mathrm{s}$. This extreme volume of water was the result, in part, of the unusual landfall of five severe tropical storms, Haima, Nok-ten, Haitang, Nesat and Nalgae, between June 2011 and October 2011 (Meteorological Department of Thailand, 2011). The rain exceeded the storage capacity of the dams and consequently it flooded the lower areas of Thailand.

Bangkok has a low lying flat topography (averaging about $2 \mathrm{~m}$ above sea level) that increased the likelihood of higher and longer flooding. Homes and commercial areas were flooded, seven industrial estates were inundated with water depths up to $6 \mathrm{~m}$ to $7 \mathrm{~m}$, and a number of universities (including the Asian Institute of Technology) were closed due to campus flooding (Figures 18.2 to 18.4 ).

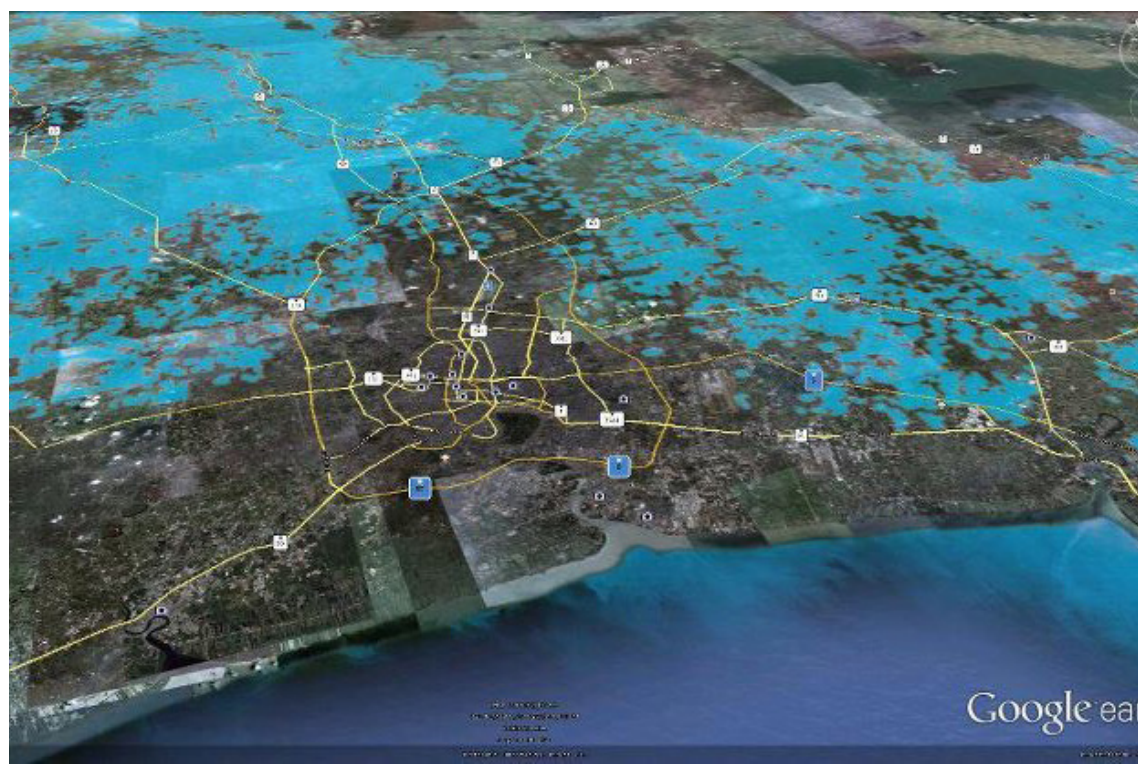

Figure 18.2 Map of Bangkok City, with blue showing the outlying flooded areas. 


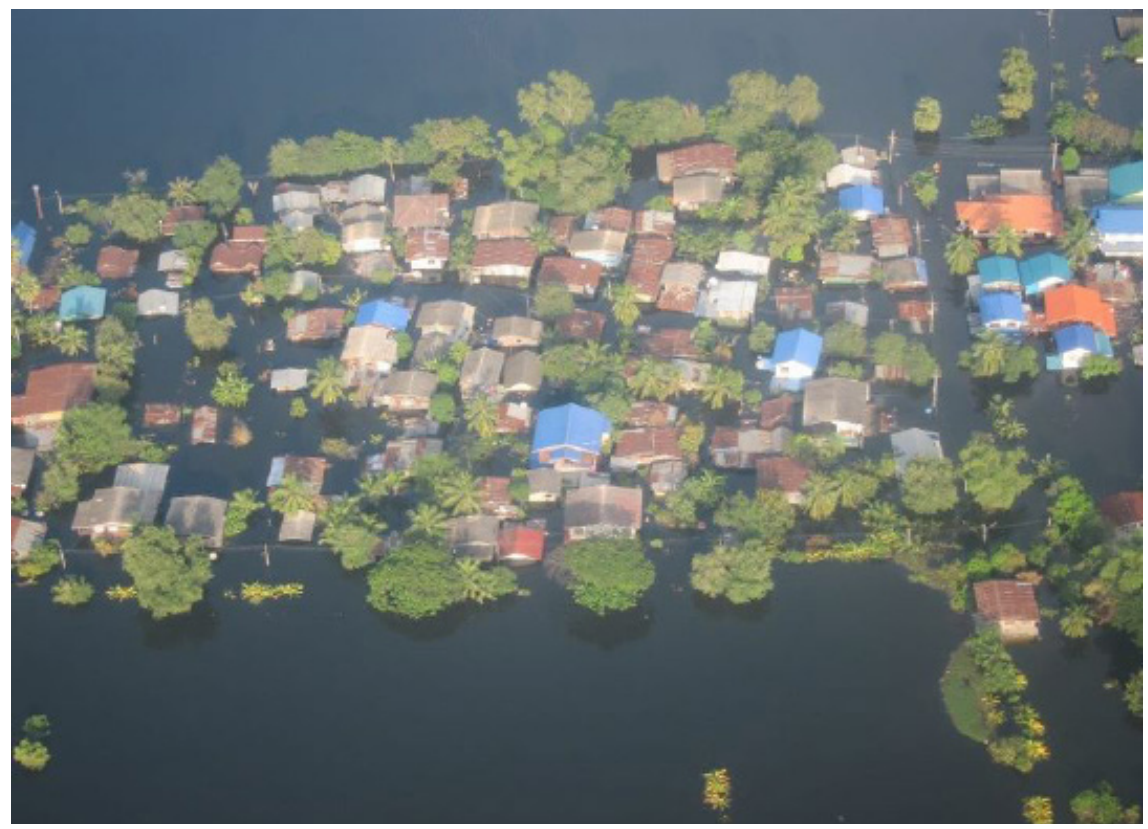

Figure 18.3 Aerial view of flooding in Bangkok, 2011.

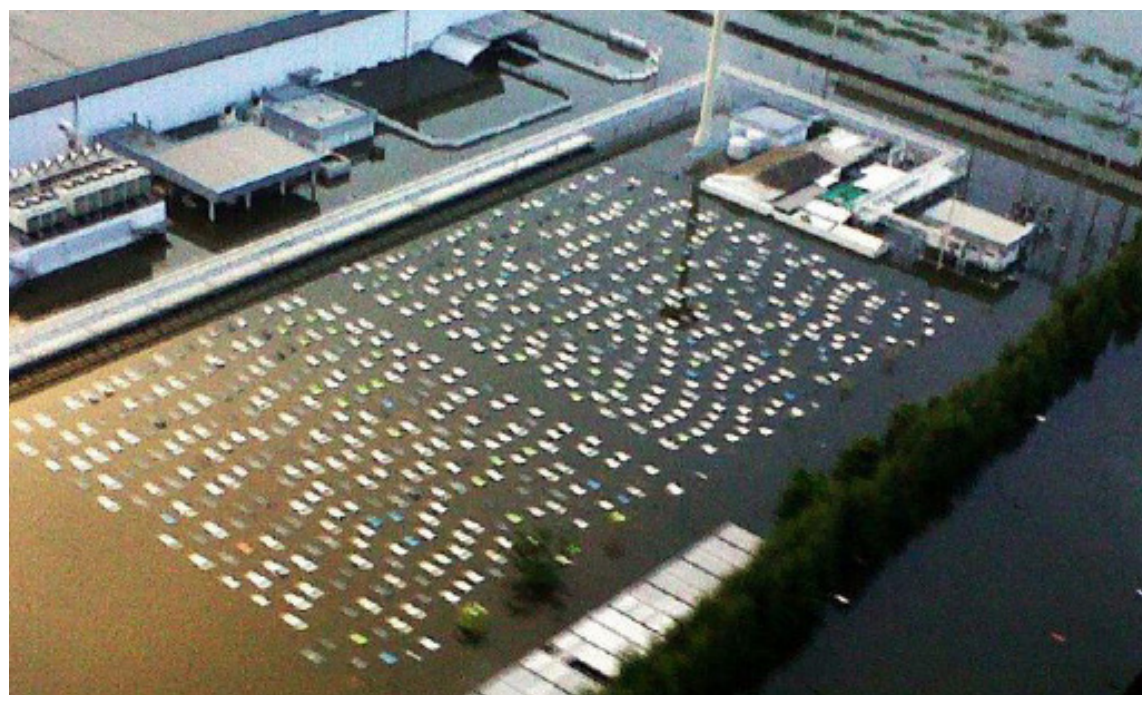

Figure 18.4 Flooding of an automobile factory in an industrial estate.

Engkagul (1993) noted that the frequency of severe flooding had increased on the lower Chao Phraya delta, recently occurring every $3 \mathrm{y}$ to $5 \mathrm{y}$. Increased flooding has been attributed to a variety of factors, including: land 
subsidence in the Bangkok area due to overpumping groundwater and urban construction; runoff increase due to urbanization; lack of systematic operation of dams and drainage; infilling of klongs (drainage canals) due to urban expansion; sedimentation in the remaining klongs; and urban encroachment directly on the klongs, which restricts flow (Engkagul, 1993; Davivongs et al., 2012; Figure 18.5).

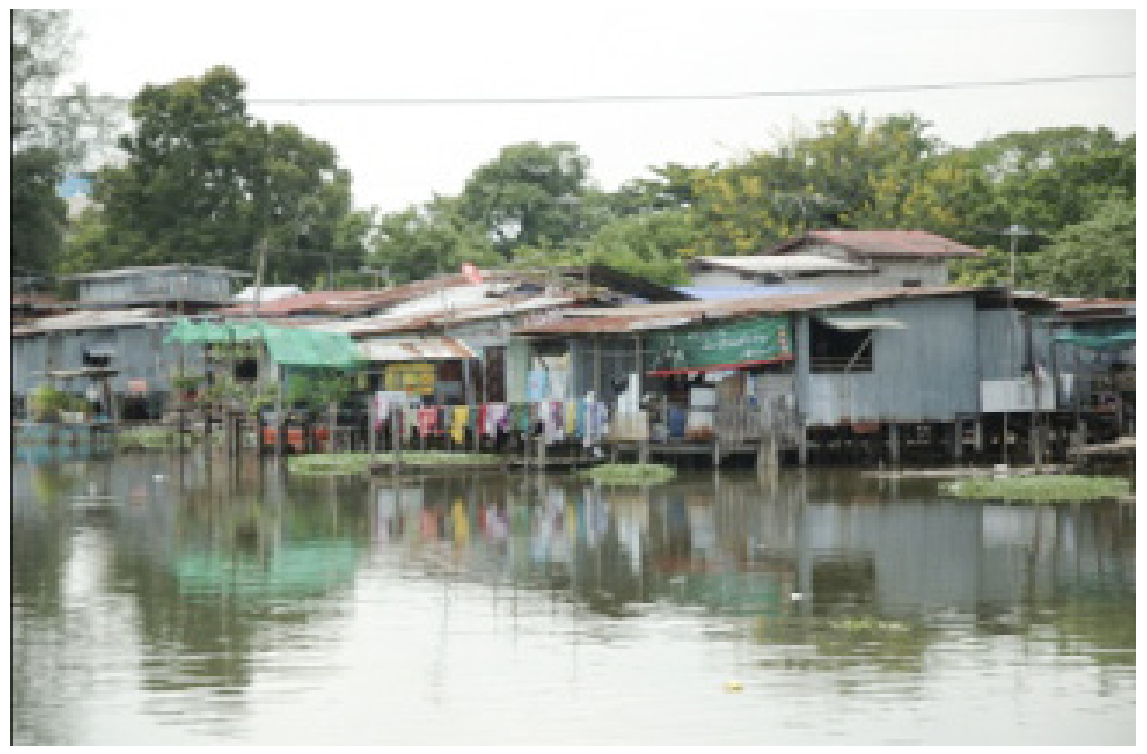

Figure 18.5 Urban encroachment on canals.

The 2011 flooding underscores the need for both short (emergency) and long term solutions to increase system resiliency. For the short term, small and big (2.5 t each) sand bags, concrete and plastic walls, and pumps were used (Figure 18.6). The emergency approach was available and affordable and was successful in keeping the core business area of Bangkok dry, although outlying areas were severely flooded. The long term solutions should include: dam operation rules to systematically control the water at upstream locations; the construction of polders and floodways to efficiently convey water to the ocean; regular dredging of the canals to facilitate floodwave movement; floodway zoning; and better modeling plans to assess the volume and flow of water in support of water management decisions.

Dynamic, graphically oriented models such as PCSWMM could be particularly helpful in representing flow and pumping operations in the dense network of canals around Bangkok. Another interesting idea is the proposal of a super floodway for the Bangkok area (Science and Development Network, 
2011) that would take advantage of existing irrigation canals running parallel to the Chao Phraya River, but also would include a $1 \mathrm{~km}$ wide buffer of empty floodway along the river.

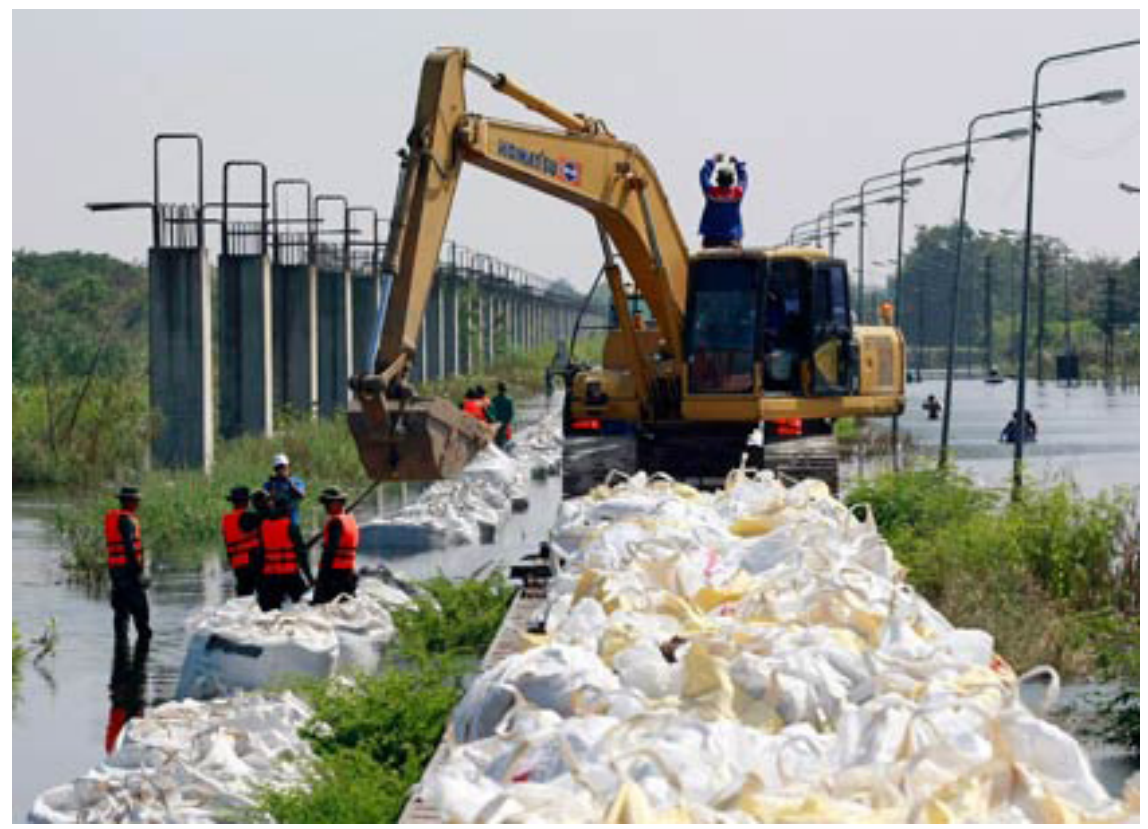

Figure 18.6 Big bags to avert flooding in Bangkok.

In addition to the large scale flooding observed in 2011, there can be problems of localized flooding in urban areas due to short term intense rainfalls. Engkagul (1993) lamented that localized flooding in Bangkok was now occurring with rainfalls of $50 \mathrm{~mm}$ as the result of increased urbanization. While improved urban stormwater management plans may have less impact on large scale flooding, they may be able to effectively alleviate the temporary local flooding observed in urban and peri-urban areas. The urban stormwater management plans should be integrated with the larger flood planning framework, particularly as it impacts land use management, although such integration can be challenging in Thailand (Lebel et al., 2011).

Rattanakosin village, in Pathum Thani province, was selected as a case study for simulating scenarios to explore the flood reduction opportunities related to localized intense rainfalls. It is a peri-urban community near Bangkok that has experienced rapid urbanization and economic growth (Ongsakul and Sajor, 2006; Pradhan and Perera, 2006; Jongkroy, 2009). Thailand's monsoon climate, together with the village's nearly flat topography and the gentle grade of the existing sewers, means that the village frequently experiences surface 
flooding. As with many communities in Thailand, the residences of the village are serviced by a septic tank, but the outflow from the tanks and combined sewage goes directly to a local canal (Kamal et al., 2008; Tsuzuki et al., 2009).

Stormwater management remains an important but complex and costly issue to tackle for the municipality, as seasonal floods cause health hazards, disruption to the residents' livelihoods, and interruptions to business activities. While there is nothing the community can do about its monsoon climate, some possible options might minimize the stormwater incidents. In a previous case study on the improvements of the combined sewer system for the village, Chaosakul et al. (2010) proposed the following options: to increase the sewer gradeline; to boost pump capacity; and to divert some flows to Boeng Yai Lake, with a constructed wetland to treat flow before it entered the lake.

There is increasing interest in low impact development (LID) technologies as a means of more sustainable urban water management (Chang, 2010; Shamsi, 2010; Pitt and Voorhees, 2011; Lawson et al., 2011; Garrison and Hobbs, 2011) and explicit consideration of LID technologies was recently included in SWMM (Rossman, 2010). LID can be an appropriate design tool for controlling runoff with the goal of mimicking a site's pre-settlement hydrology using design techniques that infiltrate, filter, store, evaporate and detain runoff close to its source. LID addresses stormwater through small and potentially cost-effective landscape features located at the lot level in contrast to the traditional approach of conveying, managing and treating stormwater in large costly end-of-pipe facilities located at the bottom of drainage areas.

Despite an increasing body of research related to LID technologies, Marsalek and Schreier (2009) noted that implementation at the municipal level has been limited. Most of the research that has been done for LID technologies focuses on temperate climates (Sidek et al., 2004; Simmons et al., 2008). Silveira (2001) and Goldenfum et al. (2007) review the challenges to implementing sustainable urban drainage, particularly in developing countries having a tropical climate. Satiennam (2006) investigated the limitations of LID implementation arising from local attitudes in the flood prone area of Bangkok's Latkrabang District, such as inadequate plot size, inadequate budget for implementation, no homeowner's time for maintenance and lack of LID gardening skills. It was concluded that LID could not be achieved if its concepts were not compatible with local conditions, and could also be constrained by the poor enforcement of flood legislation.

The challenge remains to more effectively promote LID concepts and technologies both with local citizens and the Thai government. Singapore and its Four National Taps strategy provides an important example of how LID can be effectively implemented in a tropical climate. Four National Taps seeks 
to improve Singapore's water security, with urban stormwater being one of the taps.

An initiative under this program is the conversion of Marina Bay from a tidal waterbody into a freshwater reservoir that will harvest stormwater from a third of the urban area (Wong, 2011). Singapore's economy, political will, technical expertise, and stakeholder collaboration have facilitated this ambitious plan and water resource management generally is more advanced in Singapore than in its Southeast Asian neighbours. Projects in support of the stormwater strategy include extensive characterisation studies (Chua et al., 2009; Le and Chua, 2011) and demonstration projects for rain gardens (Wong, 2011), floating wetlands (Chua et al., in press), bio-swales (Wong, 2011) and constructed wetlands (L. Chua, Nanyang Technological University, pers. comm., 201208 23). With the exception of Singapore, given the limited research in tropical areas, this study examines the design, hydrologic and water quality performance, and planning level costs associated with two LID scenarios to reduce surface flooding and combined sewer overflows (CSOs) for Ratanakosin village.

The study was conducted as part of a graduate course on sewerage design at the Asian Institute of Technology which has the specific aim of introducing the students to the use of mathematical modeling as a decision making tool in urban drainage and water quality problems. Application of dynamic, graphically oriented models for sewer analysis and design are not as common in Thailand as in the West. However, it is hoped that the combination of student training in model use and demonstration of model utility to government personnel will help to promote cost effective applications in the future.

\subsection{Methodology}

\subsubsection{Study Area}

Rattanakosin village is a typical peri-urban community of Thailand and other developing countries. The village is in Rangsit municipality located in the southern part of Pathum Thani province, Thailand. It covers an area of 2.5 $\mathrm{km}^{2}$. There is an excavated lake in the village, Boeng Yai, which has a surface area of $0.10 \mathrm{~km}^{2}$ and is $5 \mathrm{~m}$ to $7 \mathrm{~m}$ deep. The other two water bodies nearby the village are the Rangsitprayoonrasak and Premprachakorn canals. Rangsitprayoonrasak canal is in the south of the village and is $16 \mathrm{~m}$ wide and $2.5 \mathrm{~m}$ deep. It is an irrigation canal that is also used for flood protection and drains to the Chao Phraya river. Premprachakorn is an excavated canal connected to the Rangsitprayoonrasak canal for drainage and irrigation purposes. It is located in the west of the village and is $10 \mathrm{~m}$ wide and $2.1 \mathrm{~m}$ deep. 


\subsubsection{Scenario Development}

The class developed design plans for individual LID technologies using either $\mathrm{CAD}$ or Google SketchUp and these were placed throughout the village area using Google Earth for visualization and presentation purposes. An example of one of the LID designs is shown in Figure 18.7. Ultimately, the class design concepts (e.g. Figure 18.7) became the basis of, but were not identical to, the PCSWMM scenarios examined in this paper.
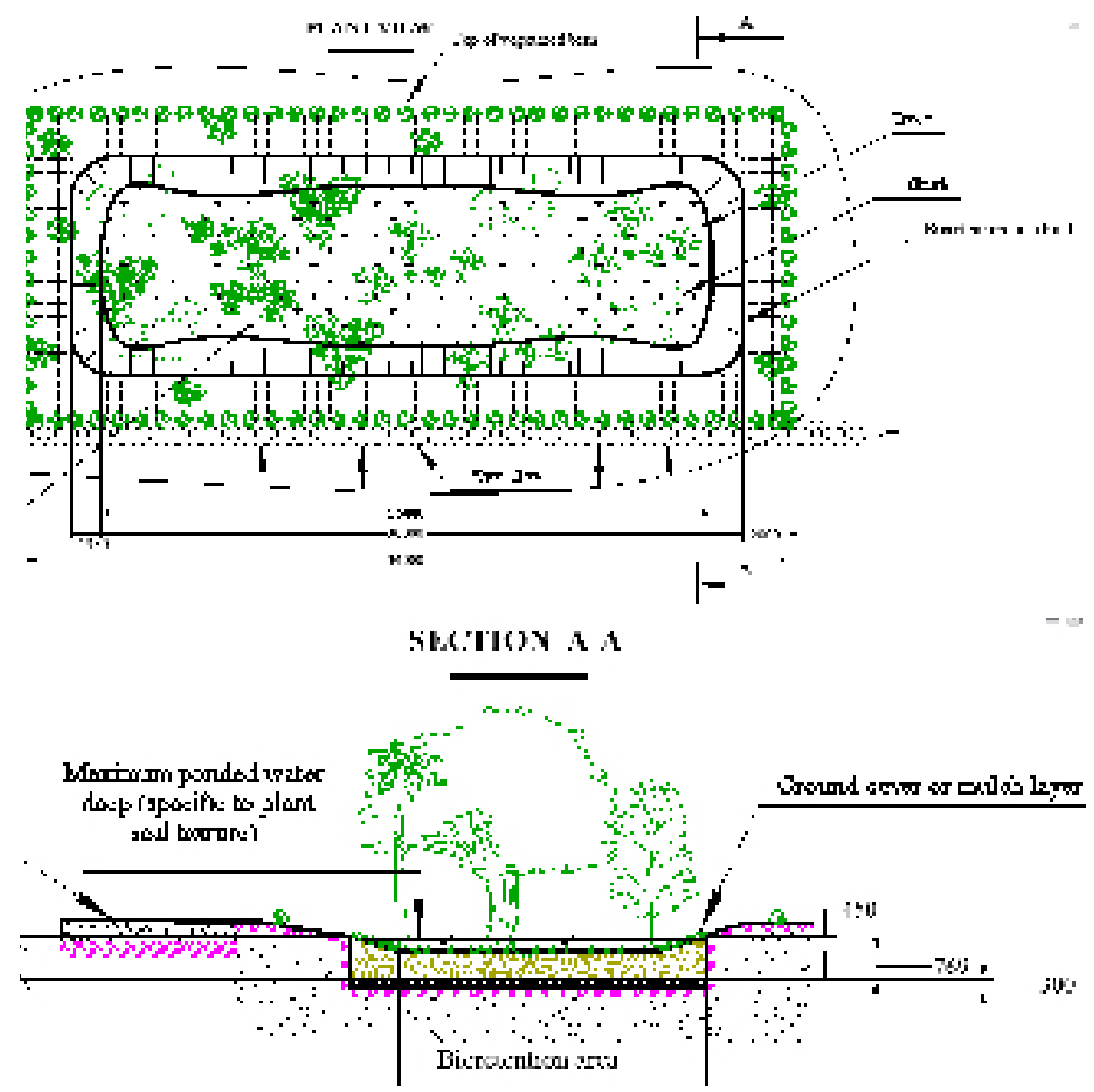

Figure 18.7 Example CAD design of a bioretention cell (units are $\mathrm{mm}$ ).

Five common types of LID (bioretention cells, vegetative swales, rain barrel, porous pavement and infiltration trenches) are programmed in SWMM and are accessed through simple dialog boxes. The LID technologies were programmed using algorithms that already existed in the SWMM engine and 
a generic LID unit is represented by a number of vertical layers (Rossman, 2010). Various parameters must be input by the users (Table 18.1).

Table 18.1 SWMM input parameter values for LID scenarios.

\begin{tabular}{|c|c|c|c|c|c|c|}
\hline \multirow[b]{2}{*}{ LID controls } & \multicolumn{3}{|c|}{ Scenario 1} & \multicolumn{3}{|c|}{ Scenario 2} \\
\hline & Input & $\begin{array}{l}\text { Number of } \\
\text { replicate units }\end{array}$ & $\begin{array}{l}\text { Area of each } \\
\text { unit }\left(\mathrm{m}^{2}\right)\end{array}$ & Input & $\begin{array}{l}\text { Number of } \\
\text { replicate units }\end{array}$ & $\begin{array}{c}\text { Area of each } \\
\text { unit }\left(\mathrm{m}^{2}\right)\end{array}$ \\
\hline $\begin{array}{l}\text { Bioretention cell } \\
\end{array}$ & & & & & $33^{2 \mathrm{a}}, 96^{2 \mathrm{~b}}$ & 3000 \\
\hline Impervious area treated $(\%)$ & & & & 50 & & \\
\hline \multicolumn{7}{|l|}{ Surface } \\
\hline Storage depth $(\mathrm{mm})$ & & & & 200 & & \\
\hline Vegetative cover (fraction) & & & & 0.7 & & \\
\hline Surface roughness (Manning's n) & & & & 0.3 & & \\
\hline Surface slope (\%) & & & & 0 & & \\
\hline \multicolumn{7}{|l|}{ Soil } \\
\hline Thickness (mm) & & & & 1075 & & \\
\hline Porosity (volume fraction) & & & & 0.5 & & \\
\hline Field capacity (volume fraction) & & & & 0.3 & & \\
\hline Wilting point (volume fraction) & & & & 0.1 & & \\
\hline Conductivity $(\mathrm{mm} / \mathrm{h})$ & & & & 10.9 & & \\
\hline Conductivity slope (\%) & & & & 10 & & \\
\hline Suction head $(\mathrm{mm})$ & & & & 110.1 & & \\
\hline \multicolumn{7}{|l|}{ Storage } \\
\hline Height $(\mathrm{mm})$ & & & & 400 & & \\
\hline Void ratio (voids/solids) & & & & 0.75 & & \\
\hline Conductivity $(\mathrm{mm} / \mathrm{h})$ & & & & 6 & & \\
\hline Clogging factor & & & & 0 & & \\
\hline \multicolumn{7}{|l|}{ Underdrain } \\
\hline Drain coefficient $(\mathrm{mm} / \mathrm{h})$ & & & & 0 & & \\
\hline Drain exponent & & & & 0 & & \\
\hline Drain offset height $(\mathrm{mm})$ & & & & 0 & & \\
\hline Rain barrel & & $\begin{array}{c}5999^{1 \mathrm{a}} \\
35964^{1 \mathrm{~b}}\end{array}$ & 1.2 & & $\begin{array}{c}35964^{2 \mathrm{a}, 2 \mathrm{~b}} \\
5999^{2 \mathrm{c}}\end{array}$ & 1.2 \\
\hline Impervious area treated (\%) & 50 & & & 50 & & \\
\hline Height (m) & 3.15 & & & 3.15 & & \\
\hline \multicolumn{7}{|l|}{ Storage } \\
\hline Volume $\left(\mathrm{m}^{3}\right)$ & 3.2 & & & 3.2 & & \\
\hline \multicolumn{7}{|l|}{ Underdrain } \\
\hline Drain coefficient $(\mathrm{mm} / \mathrm{h})$ & 0 & & & 0 & & \\
\hline Drain exponent & 0 & & & 0 & & \\
\hline Drain offset height (mm) & 0 & & & 0 & & \\
\hline Drain delay $(\mathrm{h})$ & 96 & & & 96 & & \\
\hline
\end{tabular}

${ }_{1 a,} 1 b, 2 a, 2 b, 2 c$ Superscripts refer to scenarios 1a, 1b, 2a, 2b and 2c.

Two scenarios were developed for modeling water quantity and quality in the combined sewer system for this study. Scenario 1 examined the impact and cost strictly of a rain barrel program, and Scenario 2 examined the impact and cost of rain barrel scenarios combined with construction of bioretention 
cells. Furthermore, two sub-scenarios were developed for scenario 1 and three sub-scenarios were developed for scenario 2 .

The subscenarios are as follows.

- Scenario 1a: a single $3.2 \mathrm{~m}^{3}$ rain barrel was installed at each home of the village;

- Scenario 1b: six rain barrels $\left(3.2 \mathrm{~m}^{3}\right.$ each) were installed at each home of the village;

- Scenario 2a: 33 bioretention cells (3000 $\mathrm{m}^{2}$ each) were placed in the eleven different subcatchments around the industrial and less developed periphery of the village and six rain barrels $\left(3.2 \mathrm{~m}^{3}\right.$ each) were installed at each home of the village;

- Scenario 2b: three or four bioretention cells were placed in each of the 27 subcatchments of the village and six rain barrels $\left(3.2 \mathrm{~m}^{3}\right.$ each) were installed at each home of the village; and

- Scenario 2c: 33 bioretention cells (3000 $\mathrm{m}^{2}$ each) were placed in the eleven different subcatchments around the industrial and less developed periphery of the village and one rain barrel $\left(3.2 \mathrm{~m}^{3}\right)$ was installed at each home of the village.

Scenario 1 was developed because rain barrel technology has gained a great deal of public attention in North America (e.g. http://bnriverkeeper.org/ programs/rain-barrels/) and may have the goal of capturing, at a minimum, the 5 y storm from a roof (Hager, 2003).

Rainwater harvesting also is a means by which water can be re-used for a number of domestic purposes. The rain barrel scenario was explored by first assuming each house would install one rain barrel $\left(2.0 \mathrm{~m}^{3}\right)$ and then iteratively increasing the size and number of rain barrels. We present only the results for a $3.2 \mathrm{~m}^{3}$ rain barrel size, but bracket the range of results by summarizing the impact and cost of one rain barrel or six rain barrels per house.

The largest standard rain barrel size in Thailand currently is $2 \mathrm{~m}^{3}$, but 3.2 $\mathrm{m}^{3}$ units are available in North America and could possibly be manufactured and distributed in Thailand. Traditional ceramic-cement water jars are commonly used in rural Thailand (Hewison and Tunyavanich, 1990; Phuanukoonnon et al., 2005; Dev Sehgal, 2008), so household acceptance of a rain barrel in peri-urban Thailand may be even higher than in North America. Housing density in the village presents a challenge to bioretention construction at the individual lot level.

Scenario 2 a represents the most likely bioretention placement with the maximum rain barrel placement while Scenario $2 \mathrm{~b}$ has the maximum bioretention and rain barrel placement. Scenario $2 \mathrm{c}$ represents the combination of most likely bioretention and rain barrel placement. 


\subsection{Results and Discussions}

\subsubsection{LID Scenario Simulations}

The hydrologic and water quality results for scenarios 1 and 2 are compared with the base case (current conditions) in Table 18.2 for the $2 \mathrm{y}$ design storm. The event hydrographs (inflow to the system and CSOs) for the different scenarios are shown in Figure 18.8. In comparison to the current conditions, scenario 1a reduced CSO volume by $5 \%$, the CSO pollutant load by $4 \%$ to $9 \%$, and the average duration of surface flooding was also reduced. The more aggressive rain barrel scenario, $1 \mathrm{~b}$, reduced CSO volume by $9 \%$, CSO pollutant load by $8 \%$ to $11 \%$, as well as reducing the average duration of surface flooding. Scenario $2 b$, which represented a combination of aggressive rain barrel and bioretention installation reduced CSO volume by $41 \%$, CSO pollutant load by $34 \%$ to $40 \%$, and virtually eliminated surface flooding, as compared to current conditions. Scenario $2 \mathrm{c}$ represented the most likely combination of rain barrel and bioretention technologies and decreased CSO volume by $17 \%$, CSO pollutant load by $16 \%$ to $18 \%$, and reduced the average duration of surface flooding, as compared to current conditions.

Table 18.2 LID scenario results.

\begin{tabular}{|c|c|c|c|c|c|c|c|c|c|c|c|}
\hline \multirow{2}{*}{ Item } & \multirow[b]{2}{*}{$\begin{array}{l}\text { Base } \\
\text { case }\end{array}$} & \multicolumn{2}{|c|}{ Scenario 1a } & \multicolumn{2}{|c|}{ Scenario $1 \mathrm{~b}$} & \multicolumn{2}{|c|}{ Scenario 2a } & \multicolumn{2}{|c|}{ Scenario $2 \mathrm{~b}$} & \multicolumn{2}{|c|}{ Scenario 2c } \\
\hline & & 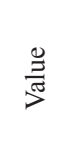 & 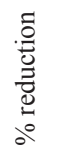 & $\stackrel{\frac{9}{\pi}}{\frac{\pi}{>}}$ & 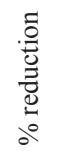 & $\frac{\mathscr{g}}{\stackrel{\pi}{\pi}}$ & $\begin{array}{l}.00 \\
.00 \\
0 \\
0 \\
0 \\
0\end{array}$ & $\frac{\mathscr{0}}{\stackrel{\pi}{\pi}}$ & $\begin{array}{l}.0 \\
.0 \\
0 \\
0 \\
0 \\
0 \\
0\end{array}$ & $\frac{\mathscr{O}}{\stackrel{\pi}{\pi}}$ & 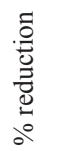 \\
\hline Total inflow $\left(10^{3} \mathrm{~m}^{3}\right)$ & 66.6 & 62.4 & 6.3 & 60.0 & 9.9 & 52.0 & 21.9 & 37.7 & 43.4 & 54.42 & 18.3 \\
\hline $\begin{array}{l}\text { Total volume to } \\
\text { outfall }\left(10^{3} \mathrm{~m}^{3}\right)\end{array}$ & 67.6 & 64.1 & 5.2 & 61.8 & 8.6 & 53.9 & 20.3 & 39.7 & 41.3 & 56.28 & 16.7 \\
\hline $\begin{array}{l}\text { Average surface } \\
\text { flooding duration }(h)^{1}\end{array}$ & 0.7 & 0.43 & 38.6 & 0.4 & 43.8 & 0.3 & 60.3 & 0.0 & 100.0 & 0.33 & 52.9 \\
\hline \multicolumn{12}{|c|}{ Subcatchment washoff $(\mathrm{kg})$} \\
\hline TSS & 3,601 & 3,102 & 13.9 & 3,037 & 15.7 & 2,655 & 26.3 & 2,086 & 42.1 & 2,717 & 24.5 \\
\hline BOD & 1,927 & 1,810 & 6.1 & 1,748 & 9.3 & 1,525 & 20.8 & 1,120 & 41.8 & 1,589 & 17.5 \\
\hline COD & 4,239 & 3,983 & 6.0 & 3,846 & 9.3 & 3,356 & 20.8 & 2,465 & 41.8 & 3,495 & 17.6 \\
\hline \multicolumn{12}{|c|}{ Total pollutant to outfall $(\mathrm{kg})$} \\
\hline TSS & 3,591 & 3,265 & 9.1 & 3,207 & 10.7 & 2,878 & 19.9 & 2,363 & 34.2 & 2,937 & 18.2 \\
\hline BOD & 1,813 & 1,735 & 4.3 & 1,676 & 7.6 & 1,467 & 19.1 & 1,078 & 40.5 & 1,530 & 15.6 \\
\hline COD & 3,988 & 3,818 & 4.3 & 3,686 & 7.6 & 3,228 & 19.1 & 2,371 & 40.5 & 3,365 & 15.6 \\
\hline
\end{tabular}

${ }^{1}$ Average of 222 locations (model nodes) in the village.

It is worth exploring model sensitivity using such plans to discover what options may be acceptable in Thailand, particularly as SWMM and many LID 
technologies were developed for temperate Western climates. As noted above, communities in the United States often seek to capture the $5 \mathrm{y}$ rain event with rain barrels, and the design storm frequency for storm sewers is $5 \mathrm{y}$ or $10 \mathrm{y}$ for residential areas and $10 \mathrm{y}$ for commercial and industrial areas. The $10 \mathrm{y}$, $24 \mathrm{~h}$, design storm for Buffalo, NY, is approximately $86 \mathrm{~mm}$ and the $100 \mathrm{y}$, $24 \mathrm{~h}$, design storm is approximately $122 \mathrm{~mm}$. The $2 \mathrm{y}$ storm for Thailand is somewhere between the $10 \mathrm{y}$ storm and the $100 \mathrm{y}$ storm in Buffalo, and Holman-Dodds et al. (2003) have shown that, in general, LID technologies become less effective at higher rainfall amounts. This issue may be reflected in the relatively small decrease in CSO volume associated with scenario 1a. It was beyond the scope of this study to assess the possible benefits of rainwater harvesting using the rain barrels, as was done by Pitt and Vorhees (2011), but such considerations should be included in the future. Scenario 2 resulted in decreases for all hydrologic and water quality parameters and it appears that inclusion of multiple LID technologies within an urban area may be of benefit. Scenario $2 b$ likely is overly optimistic as far as the combination of maximum rain barrel and bioretention coverage, but it does illustrate the level of management that could be achieved. While the bioretention cells can be aesthetically pleasing, as well as hydrologically and environmentally beneficial, larger parcels of land must be identified for construction (Table 18.1 above).

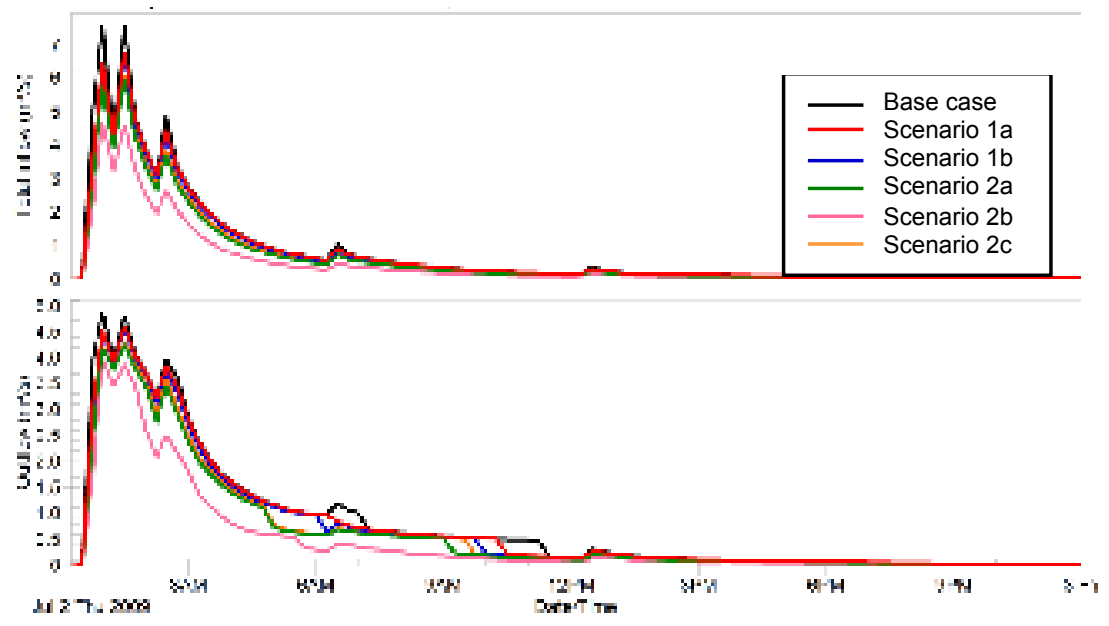

Figure 18.8 Comparison of runoff and CSO results between the existing case and scenarios.

\subsubsection{Cost Estimation}

Costs for each of the two scenarios (in USD, 2011) were estimated from a combination of discussions with local contracting companies, standard design 
manuals and internet searches. The cost for each design is summarized in Table 18.3. The costs in Table 18.3 strictly reflect the construction of the units and as such are low estimates since they do not include design or maintenance costs. Maintenance costs, in particular, are difficult to estimate in Thailand as there essentially is no experience with these technologies. It is likely that the rain barrels would become the responsibility of the individual home owner, while the bioretention cells might be maintained by the municipality, or through public-private partnerships.

Table 18.3 Cost estimates for LID scenarios.

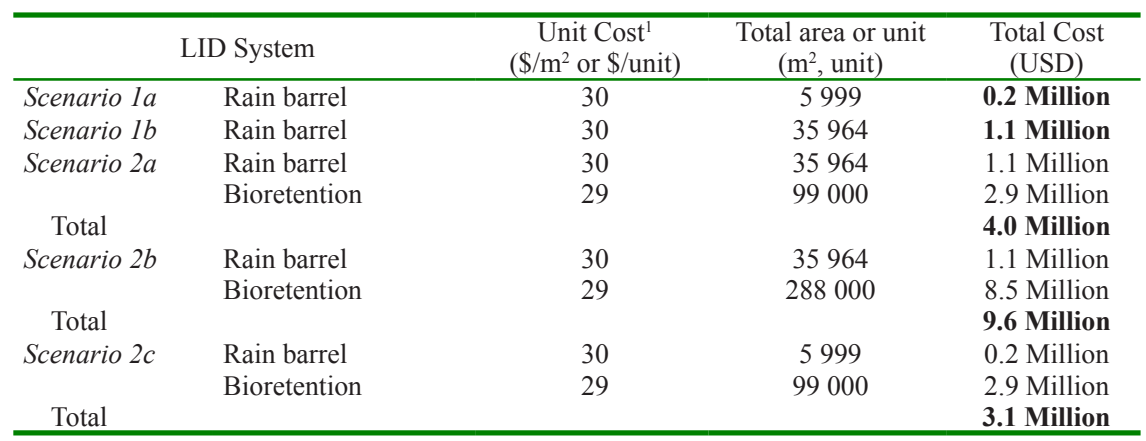

${ }^{1}$ Unit number for rain barrels; area for bioretention cells.

\subsection{Conclusions}

There is increasing interest in LID technologies as a more sustainable approach to urban stormwater management. LID options were recently included by the USEPA in SWMM (Rossman, 2010) and these options were used to develop scenarios for stormwater management in Rattanakosin village. All scenarios reduced surface flooding and CSO discharges, but the construction costs may be prohibitive in Thailand, particularly for scenario 2 , the combination of rain barrels and bioretention cells (which also produced the greatest level of water management). Montalto et al. (2007) argued that life cycle costing, water reuse benefits and public-private partnerships make LID implementation attractive in North America. It is unclear whether such economic arguments would be accepted in Thailand, but the issue should be explored. Certainly the catastrophic flooding of 2011 may provide impetus to consider innovative stormwater management options. Finally, it is important to note that we used only the $2 \mathrm{y}$ design storm for Thailand in this study. Many LID technologies (including those programmed in SWMM) were developed for temperate climates with smaller rainfalls and generally such technologies be- 
come less effective with larger storm events. This is likely the reason we had to include such a large number of rain barrels, for example, to produce even a $10 \%$ reduction in CSO volume. This issue must be examined in greater detail if LID approaches are to be optimized for Southeast Asia and other tropical regions.

\section{Acknowledgments}

Funding for the AIT PCSWMM license was partially provided by a grant from the International Foundation for Science under its Sustainable Wastewater Treatment program. Financial support for the fieldwork was partly contributed from the Swiss funded National Center for Competence in Research (NCCR) North-South program and by Buffalo State University. The field work and initial design work by master's students from AIT: J. Bowles, S. Rattanakul, N. Pradhan, W. Simphan, A. Ghimire, K. Wilaingam, L. M. Truong, T. V. Nguyen, T. Pussayanavin, N. Proysurin, S. Singjan, V. Longaphai, S. N. Kalaimathy and J. Price are gratefully acknowledged. This manuscript was completed while K. N. Irvine was on sabbatical at the National Institute of Education, Nanyang Technological University, Singapore.

\section{References}

Chaleeraktrakoon, C. and Kangrang, A. 2007. Dynamic programming with the principle of progressive optimality for searching rule curves. Can. J. Civ. Eng., 34: 170-176.

Chang, N.B. 2010. Hydrological connections between low-impact development, watershed best management practices, and sustainable development. Journal of Hydrologic Engineering, June, 384-385.

Chaosakul, T., Wijekoon, K.C., Kijjanapanich, P., Udom, T., Siripong, C., Dang, N.H., Sin, K., Samantarat, N., Koottatep, T., Irvine, K.N., Zumfelde, J. and Bakert, J. 2010. Modeling a peri-urban combined sewer system to assess drainage improvements: A case study of Rattanakosin Village, Thailand. In: Southeast Asian Water Environment 4, K. Fukushi, F. Kurisu, K. Oguma, H. Furamai, and P. Fontanos (Eds), IWA Publishing, U.K. ISBN 9781843393627.

Chua, L.H.C., Lo, Y.M.E., Shuy, E.B., and Tan, B.K.S., 2009. Nutrients and suspended solids in storm runoff from catchments with various proportions of rural and urban land use in Kranji Catchment, Singapore. Journal of Environmental Management, 90: 3635-3642.

Chua, L.H.C., Tan, S.B.K., Sim, C.H. and Goyal, M.K. In press. Treatment of baseflow from an urban catchment by a floating wetland system. Ecological Engineering.

Davivongs, V., Yokohari, M., and Hara, Y. 2012. Neglected canals: Deterioration of indigenous irrigation system by urbanization in the west peri-urban area of Bangkok Metropolitan Region. Water, 4: 12-27. 
Dev Sehgal, J. 2008. Roof-top harvesting of rainwater: A sustainable water resource in S.E. Asia. In $4^{\text {th }}$ International Conference on Sustainable Water Environment: Innovative Technologies and Energy Efficient Solutions, Singapore, 17-19 November, 2008.

Engkagul, S. 1993. Flooding features in Bangkok and vicinity: Geographical approach. GeoJournal, 31(4): 335-338.

Garrison, N. and Hobbs, K. 2011. Rooftops to Rivers II: Green Strategies for Controlling Stormwater and Combined Sewer Overflows. Natural Resources Defense Council, New York, NY.

Goldenfum, J.A., Tassi, R., Meller, A., Allasia, D.G., and Silveira, A.L. 2007. Challenges for the sustainable urban stormwater management in developing countries: From basic education to technical and institutional issues. In: 6th International Conference on Sustainable Techniques and Strategies in Urban Water Management, Novatech 2007, Lyon, 25-28 June, 2007.

Hager, M.C. 2003. Low-impact development. Stormwater, January-February, http://www. lowimpactdevelopment.org/lid\%20articles/stormwater_feb2003.pdf.

Hewison, K. and Tunyavanich, N. 1990. Rainwater storage in cement jars in Northeastern Thailand. International Journal of Water Resources Development, 6(2): 129-136.

Holman-Dodds, J.K., Bradley, A.A., and Potter, K.W. 2003. Evaluation of hydrologic benefits of infiltration based urban storm water management. Journal of the American Water Resources Association, 39(1), 205-215.

Jongkroy, P. 2009. Urbanization and changing settlement patterns in peri-urban Bangkok. Kasetsart J. (Soc. Sci.), 30: 303-312.

Kamal, A.S.M., Goyer, K., Koottatep, T. and Amin, A.T.M.N. 2008. Domestic wastewater management in South and Southeast Asia: the potential benefits of a decentralised approach. Urban Water Journal, 5, 345 -354.

Le, S.H. and Chua, H.C.L. 2011. Sensitivity study of washoff parameters for simulation of total suspended solids concentrations from storm runoff. In: Proceedings of the $15^{\text {th }}$ International Conference of the IWA Special Group on Diffuse Pollution (DIPCON2011), Rotorua, New Zealand.

Lebel, L., Manuta, J.B., and Garden, P. 2011. Institutional traps and vulnerability to changes in climate and flood regimes in Thailand. Reg. Environ. Change, 11: 45-58.

Lawson, S., D. Joksimovic, J. Li and M. Walters. 2011. "The Perceptions of Stakeholders in Low Impact Development Planning." Journal of Water Management Modeling R241-19. doi: 10.14796/JWMM.R241-19.

Marsalek, J. and Schreier, H. 2009. Innovation in stormwater management in Canada: The way forward. Water Quality Research Journal of Canada, 44(1): v-x.

Meteorological Department of Thailand, 2011. http://www.tmd.go.th/

Molle, F. 2004. Technical and institutional responses to basin closures in the Chao Phraya River Basin, Thailand. Water International, 29(1): 70-80.

Montalto, F., Behr, C., Alfredo, K., Wolf, M., Arye, M., and Walsh, M. 2007. Rapid assessment of the cost-effectiveness of low impact development for CSO control. Landscape and Urban Planning, 82: 117-131.

Ongsakul, R. and Sajor, E.E. 2006. Water governance in mixed land use: a case study of Rangsit Field, peri-urban Bangkok. In: Proceedings: Regional Conference on Urban Water and Sanitation in Southeast Asian Cities, AIT, pp. 329-340. 
Phuanukoonnon, S., Mueller, I., and Bryan, J.H. 2005. Effectiveness of dengue control practices in household water containers in Northeast Thailand. Tropical Medicine and International Health, 10(8): 755-763.

Pitt, R.E. and J. Voorhees. 2011. "Modeling Green Infrastructure Components in a Combined Sewer Area." Journal of Water Management Modeling R241-08. doi: 10.14796/JWMM.R241-08.

Pradhan, P. and Perera, R. 2006. Impact of urbanization on the water resources and public health in Pathumthani Province, Thailand. In: Proceedings: Regional Conference on Urban Water and Sanitation in Southeast Asian Cities, AIT, pp. 87-102.

Rossman, L.A. 2010. "Modeling Low Impact Development Alternatives with SWMM." Journal of Water Management Modeling R236-11. doi: 10.14796/JWMM.R236-11.

Royal Irrigation Department, Thailand,2011. http://www.rid.go.th

Satiennam, T. 2006. Adoption of low impact development (LID) at site level for mitigating conflict in flood prone area: A study of the Latkrabang District in Bangkok, Thailand. AIT master thesis, 2006.

Science and Development Network, 2011. http://www. scidev.net.

Shamsi, U.M. 2010. "Low Impact Development for Stormwater Quantity and Quality." Journal of Water Management Modeling R236-13. doi: 10.14796/JWMM.R236-13.

Sidek, L.M., Takara, K., Zakaria, N.A., Ghani, A.A., and Abdullah, R. 2004. An assessment of stormwater management practices using MSMA Manual in Malaysia. $1^{s t}$ International Conference on Managing Rivers in the $21^{\text {st }}$ Century: Issues \& Challenges, pp. 479-495.

Silveira, A.L.L. 2001. Problems of urban drainage in developing countries. In: International Conference on Innovative Technologies in Urban Storm Drainage, Novatech 2001, Lyon, 25-27 June, 2001.

Simmons, M.T., Gardiner, B., Windhager, S., and Tinsley, J. 2008. Green roofs are not created equal: The hydrologic and thermal performance of six different extensive green roofs and reflective and non-reflective roofs in a sub-tropical climate. Urban Ecosyst., 11: 339-348.

Thailand Research Fund, 2011, http://pr.trf.or.th

Tsuzuki, Y., Koottatep, T., Wattanachira, S., Sarathai, Y., and Wongburana, C. 2009. Onsite treatment systems in the wastewater treatment plants (WWTPs) service areas in Thailand: scenario based pollutant loads estimation. Journal of Global Environmental Engineering, 14, 57-65.

Yoshito, Y., Pongsak, A., Katsuro, S., Tatsuji, O., Noboru, N., and Takashi, F. 2003. Improvement of Water Allocation Planning and Practical Operation in the Upper East Bank of The Chao Phraya Delta. Technical Report National Institute of Rural Engineering Japan. Report Number 201, pp. 93-124.

Wong, T.H.F. 2011. Framework for stormwater quality management in Singapore. In: $12^{\text {th }}$ International Conference on Urban Drainage, Porto Alegre, Brazil, 11-16 September, 2011. 
